\title{
Child Neurology: Friedreich ataxia with upper motor neuron findings
}

\section{A case study}

Elizabeth A. Harvey, MD, and Kimberly S. Jones, MD

Neurolog ${ }^{\circledR}$ 2018;91:426-428. doi:10.1212/WNL.0000000000006086
Correspondence

Dr. Jones

Kimberly.jones2@uky.edu

\begin{abstract}
A 16-year-old boy with hypertrophic cardiomyopathy, gait abnormalities, and balance problems was found to have Friedreich ataxia. Though Friedreich ataxia typically renders patients areflexic, this child had upper motor neuron findings of spasticity in both lower extremities, with crossed adductors, and 4+ deep tendon reflexes at the patella and Achilles bilaterally. This unusual presentation of an uncommon genetic disorder led to uncertainty of the patient's true diagnosis until genetic testing confirmed that he had 2 alleles with the Friedreich ataxia mutation.
\end{abstract}

\section{Introduction}

Friedreich ataxia is an autosomal recessive genetic disease that occurs due to a trinucleotide expansion in the frataxin gene on chromosome 9. This homozygous trinucleotide expansion in the FXN gene leads to decreased production of frataxin. This impairs mitochondrial electron transport and interferes with cellular metabolism. Eventually this leads to atrophy of the dorsal root ganglia, further degeneration of the dorsal columns, and the gracile and cuneate nuclei proceed from there. ${ }^{1}$ The FXN expansion is unstable and can lengthen when passed from parent to child, worsening the child's phenotype in a process called anticipation.

Friedreich ataxia is characterized by progressive ataxia of gait as well as hypertrophic cardiomyopathy. A common physical examination finding in such cases is the absence of deep tendon reflexes. ${ }^{2}$ This case report describes the diagnosis of a patient with Friedreich ataxia who had retained deep tendon reflexes, while also showing evidence of upper motor neuron findings of spasticity in both lower extremities, with crossed adductors, and 4+ deep tendon reflexes at the patella and Achilles bilaterally.

\section{Case report}

A 16-year-old Caucasian boy presented after a fall in his home. Though it was initially thought to be a syncopal episode, it became clear that he had lost his balance in the bathroom and fallen, but had never lost consciousness. On arrival, his troponin was elevated $(0.0530 \mathrm{ng} / \mathrm{mL})$, and his ECG showed t-wave inversion in inferolateral leads, with occasional premature ventricular contractions and premature atrial contractions. His echocardiogram showed hypertrophic cardiomyopathy with preserved ejection fraction and no left ventricular outflow tract obstruction. $\mathrm{He}$ was then transferred to the pediatric intensive care unit for monitoring on telemetry.

Upon further discussion, the patient revealed a 2-year history of balance problems and dizziness that had worsened over time. He reported that his problems with balance were most noticeable when he would try to stand up after sitting in a chair, and he had coordination problems while running, feeling like his limbs were difficult to control. He described instances when his legs 


\section{Glossary}

FARR $=$ Friedreich ataxia with retained reflexes.

would feel wobbly after standing for prolonged periods. $\mathrm{He}$ also described having pain in his feet while standing or walking, which caused him to develop the habit of walking on his toes. There was a significant family history of cardiac disease on his father's side, including a paternal uncle who died at age 39 , but no history of gait or balance abnormalities.

The patient's neurologic examination showed a mild bilateral nystagmus with mild ocular ataxia, an intact sensory examination including normal position and vibratory sense, $2+$ bilateral upper extremity reflexes, 4+ bilateral patellar and Achilles reflexes, with sustained clonus, and upgoing plantar reflexes. He was found to have mild to moderate ataxia with dysmetria on both finger-to-nose and heal-to-shin testing bilaterally. His gait was wide-based, with a positive Romberg test, and an inability to stand with his feet together without swaying.

Genetic testing confirmed the diagnosis of Friedreich ataxia, as the patient had a GAA repeat expansion on both of his frataxin alleles. One had 1,070 repeats and the other had 830 repeats; the normal range is $12-33$ repeats. MRI of the brain and spine showed no significant abnormalities.

\section{Differential diagnosis}

Neurology was consulted because of the patient's progressive ataxia, which has a broad differential. Friedreich ataxia was considered, but on examination the patient retained reflexes in his extremities, which is atypical of the classic description of Friedreich ataxia, in which the reflexes are absent. Due to the upper motor neuron findings, as well as preserved reflexes, the differential diagnosis remained broad, and included mitochondrial disorders. Spinocerebellar ataxia and CharcotMarie-Tooth polyneuropathy were also considered. Autosomal recessive ataxia with oculomotor apraxia type 2 was also on the differential; however, the patient did not have any visual symptoms, and his MRI did not show atrophy of the cerebellar vermis. After it was found that the patient had hypertrophic cardiomyopathy, the likelihood of his having Friedreich ataxia increased significantly. Given the high suspicion of Friedreich ataxia, we opted to send the Friedreich ataxia genetic test and wait for the results before performing a muscle biopsy.

\section{Management}

The patient underwent cardiac catheterization and loop recorder placement. He was recommended for outpatient physical therapy, and for follow-up with Genetics, Neurology, and Cardiology.

\section{Discussion}

In our patient, the retained reflexes and upper motor neuron findings on examination complicated the diagnosis of Friedreich ataxia. Given these atypical findings, we needed to review the available literature on the subject. This is an unusual presentation of Friedreich ataxia. ${ }^{3}$ There are reports of other cases in which the patients had retained reflexes, which have engendered the use of the title Friedreich ataxia with retained reflexes (FARR) to describe such findings. ${ }^{4}$ One study examining FARR mutations showed that the average expansion was slightly smaller (408 \pm 252 vs $719 \pm 184$ GAA triplets) in patients with FARR when compared to patients with Friedreich ataxia. ${ }^{5}$ However, our patient's expansion sizes were greater comparable to the average Friedreich ataxia expansion, despite his having retained reflexes. One study investigated 2 patients with Friedreich ataxia who had delayed onset of symptoms and also had retained reflexes. They had relatively short trinucleotide repeat sequences, and the somatic instability had led to a mixture of GAA-44 and GAA-66 repeats. It is speculated that the instability of these borderline genes can cause a milder Friedreich ataxia phenotype. ${ }^{6}$ However, in another study that included patients with Friedreich ataxia who had retained reflexes or hyperreflexia, a commonality in repeat length or age at onset was not found. ${ }^{7}$

Another mutation associated with FARR is a point mutation at base 493 in the FXN gene that was seen in a patient with Friedreich ataxia who had retained reflexes. ${ }^{8}$ A different case report mentioned a missense mutation at G130V in the FXN gene that caused a child with Friedreich ataxia to have retained reflexes. ${ }^{9}$ Studies have shown that up to $4 \%$ of those with Friedreich ataxia have a trinucleotide expansion on one gene and a point mutation on the other, making it necessary to perform genetic sequencing whenever Friedreich ataxia is suspected. ${ }^{10}$

The reason reflexes are retained, or even increased, is not clearly understood. The reflex arc is still intact, allowing for expression of corticospinal signs. Coppola et al. ${ }^{5}$ proposed that this depends on persistence of a number of Ia sensory fibers. Vibratory sense is also preserved or mildly impaired in patients with FARR, possibly because of relative preservation of more axons in the central tracts of the dorsal columns compared to typical Friedreich ataxia. However, these examination findings do not extinguish as the disease progresses, indicating that there are other factors involved.

Due to Friedreich ataxia's rare occurrence, and the further irregularity of having retained reflexes, it was difficult to make the Friedreich ataxia diagnosis in this patient clinically. The genetic test takes weeks to come back, and the decision to wait for these 
results before beginning an expensive and invasive workup of other mitochondrial diseases was wise. Increased awareness of this unusual presentation of Friedreich ataxia might lead other clinicians to the correct conclusion in their practice.

\section{Study funding}

No targeted funding reported.

\section{Disclosure}

The authors report no disclosures relevant to the manuscript. Go to Neurology.org/N for full disclosures.

\section{References}

1. Koeppen AH, Mazurkiewicz JE. Friedreich ataxia: neuropathology revised. J Neuropathol Exp Neurol 2013;72:78-90.
2. Parkinson MH, Boesch S, Nachbauer W, Mariotti C, Giunti P. Clinical features of Friedreich's ataxia: classical and atypical phenotype. J Neurochem 2013;126: $103-117$.

3. Verma R, Gupta M. Freidreichs ataxia with retained reflexes: a phenotype and genotype correlation. BMJ Case Rep 2012;2012:bcr2012007496.

4. Klockgether T, Zuhlke C, Schulz JB, et al. Friedreichs ataxia with retained tendon reflexes: molecular genetics, clinical neurophysiology, and magnetic resonance imaging. Neurology 1996;46:118-121.

5. Coppola G, Michele GD, Cavalcanti F, et al. Why do some Friedreichs ataxia patients retain tendon reflexes? J Neurol 1999;246:353-357.

6. Sharma R, De Biase I, Gómez M, Delatycki MB, Ashizawa T, Bidichandani SI. Friedreich ataxia in carriers of unstable borderline GAA triplet-repeat alleles. Ann Neurol 2004;56:898-901.

7. Moseley ML, Benzow KA, Schut LJ, et al. Incidence of dominant spinocerebellar and Friedreich triplet repeats among 361 ataxia families. Neurology 1998;51:1666-1671.

8. Mccormack ML. Frataxin point mutations in two patients with Friedreich's ataxia and unusual clinical features. J Neurol Neurosurg Psychiatry 2000;68:661-664.

9. Caron E, Burns D, Castro D, Iannaccone ST. Atypical presentation for Friedreich ataxia in a child. J Clin Neuromuscul Dis 2015;17:13-17.

10. Heidari MM, Khatami M, Pourakrami J. Novel point mutations in frataxin gene in Iranian patients with Friedreich ataxia. Iranian J Child Neurol 2014;8:32-36.

\section{Neurology.org/N Offers Important Information to Patients and Their Families}

The Neurology ${ }^{\circledR}$ Patient Page provides:

- A critical review of ground-breaking discoveries in neurologic research that are written especially for patients and their families

- Up-to-date patient information about many neurologic diseases

- Links to additional information resources for neurologic patients

All Neurology Patient Page articles can be easily downloaded and printed, and may be reproduced to distribute for educational purposes.

Click on the 'Patients' link on the home page (Neurology.org/ $\mathrm{N}$ ) for a complete index of Patient Pages.

\section{Sign Up for the AAN's Axon Registry}

The AAN encourages its US members to show their interest in participating in the Axon Registry ${ }^{\circledR}$ by signing up today.

Use the Axon Registry to:

- Simplify reporting requirements under MACRA's Quality Payment Program and avoid penalties while reducing your administrative burden

- Meet your MOC Part IV requirements and waive up to eight credits of Part II Self-Assessment

- Choose from 22 AAN neurology-specific quality measures that fit your practice

- Use data to understand your practice and identify where improvements can be made to patient care

- Manage your patients at a population level; look at a specific group of patients based on conditions, risk factors, demographics or outcome

- Demonstrate your value to payers when negotiating reimbursement

- Enjoy multi-year, fee-free access when you sign the agreements and integrate your EHR with the registry

Learn more at AAN.com/view/Axon and send your questions to registry@aan.com. 


\section{Neurology}

Child Neurology: Friedreich ataxia with upper motor neuron findings: A case study Elizabeth A. Harvey and Kimberly S. Jones

Neurology 2018;91;426-428

DOI 10.1212/WNL.0000000000006086

This information is current as of August 27, 2018

$\begin{array}{ll}\begin{array}{l}\text { Updated Information \& } \\ \text { Services }\end{array} & \begin{array}{l}\text { including high resolution figures, can be found at: } \\ \text { http://n.neurology.org/content/91/9/426.full }\end{array} \\ \text { References } & \text { This article cites } 10 \text { articles, } 4 \text { of which you can access for free at: } \\ & \text { http://n.neurology.org/content/91/9/426.full\#ref-list-1 } \\ \text { Subspecialty Collections } & \text { This article, along with others on similar topics, appears in the } \\ & \text { following collection(s): } \\ & \text { All Pediatric } \\ \text { http://n.neurology.org/cgi/collection/all_pediatric } & \\ \text { Gait disorders/ataxia } & \\ \text { http://n.neurology.org/cgi/collection/gait_disorders_ataxia } & \text { Trinucleotide repeat diseases } \\ & \text { http://n.neurology.org/cgi/collection/trinucleotide_repeat_diseases } \\ & \text { Information about reproducing this article in parts (figures,tables) or in } \\ & \text { its entirety can be found online at: } \\ & \text { http://www.neurology.org/about/about_the_journal\#permissions } \\ \text { Permissions \& Licensing } & \text { Information about ordering reprints can be found online: } \\ & \text { http://n.neurology.org/subscribers/advertise }\end{array}$

Neurology ${ }^{\circledR}$ is the official journal of the American Academy of Neurology. Published continuously since 1951, it is now a weekly with 48 issues per year. Copyright (O 2018 American Academy of Neurology. All rights reserved. Print ISSN: 0028-3878. Online ISSN: 1526-632X.

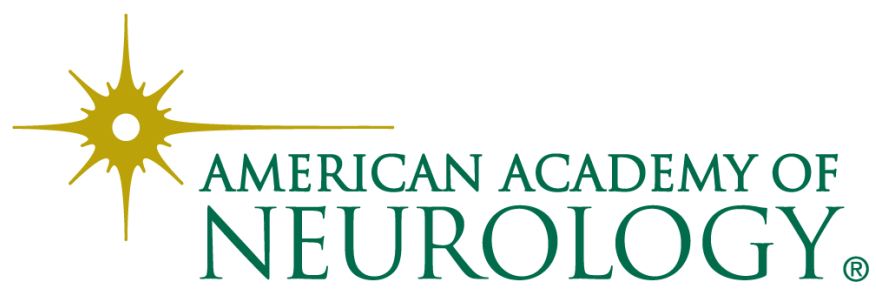

